\title{
UPAYA PEMERINTAH DALAM MEREALISASIKAN KEMUDAHAN BERUSAHA DI INDONESIA
}

\author{
(The Government Efforts In Realizing Ease of Doing Business in Indonesia)
}

\author{
Edward James Sinaga \\ Pusat Pengkajian dan Pengembangan Kebijakan \\ Balitbang Hukum dan HAM Kementerian Hukum dan HAM RI \\ JI. H.R. Rasuna Said Kav 4-5 Kuningan, Jakarta Selatan 12020, Telp. (021)2526179 \\ Email: edwardjames88@ymail.com
}

Naskah diterima: 16 Juli 2017; revisi: 13 November 2017; disetujui: 22 November 2017

\begin{abstract}
Abstrak
Pemerintah memberikan perlindungan berusaha antara lain melalui kepastian hukum dan kemudahan berusaha. Berbagai permasalahan dalam pengaturan mengenai perseroan terbatas memperlambat peningkatan pembangunan ekonomi nasional dan iklim investasi serta kemudahan berusaha. Hasil survei kemudahan berusaha Bank Dunia awal tahun 2017, menempatkan Indonesia pada peringkat ke-91. Penelitian ini melalui metode yuridis normatif berupaya menganalisis beberapa peraturan perundang-undangan yang mengatur kegiatan berusaha di Indonesia terkait implikasi pengaturan dan,-upaya perbaikan kemudahan berusaha, serta peran strategis Kementerian Hukum dan Hak Asasi Manusia dalam mendukung kemudahan berusaha. Hasil penelitian menunjukan peraturan perundang-undangan atau kebijakan yang dikeluarkan oleh pemerintah telah memberikan dorongan para investor untuk menanamkan modalnya di Indonesia. Realisasi kemudahan berusaha telah dilakukan dengan memperkecil jumlah prosedur, mengurangi waktu pengurusan, dan mengurangi biaya dengan merevisi peraturan teknis di masing-masing kementerian dan lembaga terkait. Selain daripada itu guna mendukung kemudahan berusaha maka perlu segera merealisasikan perubahan pengaturan perseroan terbatas dan pengaturan kepailitan melalui pengubahan kedua pengaturan tersebut.
\end{abstract}

Kata Kunci: kemudahan berusaha, perseroan terbatas, penanaman modal

\begin{abstract}
The government provides business protection through legal certainty and ease of doing business. The problems in limited liability company regulations slow down the increase of national economic development, investment climate, and ease of doing business. Acording to the world Bank's survey in the early 2017 Indonesia is ranked 91 out of 190 countries. Through normative juridical method, this research attempts to analyze some of the legislation governing business activities in Indonesia related to regulatory implications and the efforts to improve the ease of business, as well as the strategic role of the Ministry of Law and Human Rights in supporting of ease of doing business. Legislation or policies issued by the government have given investors impetus to invest their capital. The realization of ease of doing business has been made by minimizing the number of procedures, reducing the time of handling, and reducing costs by revising the technical regulations in the respective ministries and agencies. To support the ease of doing business it is necessary to immediately change the arrangements of limited liability companies and the bankruptcy arrangements.
\end{abstract}

Keywords: ease of doing business, limited liability company, investment 


\section{A. Pendahuluan}

Pemerintah sebagai penyelenggara negara mempunyai peran penting dan strategis dalam pembangunan ekonomi yang bertujuan meningkatkan kualitas kehidupan dan kesejahteraan semua warganya. ${ }^{1}$ Wujud peran serta negara dalam memberikan perlindungan bagi seluruh masyarakat Indonesia di sektor ekonomi antara lain melalui pembentukan Undang-Undang Nomor 40 Tahun 2007 tentang Perseroan Terbatas (UU PT) ${ }^{2}$ dan Undang-undang Nomor 25 Tahun 2007 tentang Penanaman Modal (UU Penanaman Modal). Kedua undang-undang tesebut lahir untuk mewujudkan perekonomian nasional sebagaimana yang diamanatkan Pasal 33 UUD NRI Tahun 1945.

Dalam menghadapi perubahan perekonomian global dan keikutsertaan Indonesia dalam berbagai kerja sama internasional perlu diciptakan iklim penanaman modal yang kondusif, promotif, memberikan kepastian hukum, keadilan, dan efisien dengan tetap memperhatikan kepentingan ekonomi nasional. Hal ini bertujuan untuk mempercepat pembangunan ekonomi nasional, dan salah satu langkah yang diperlukan adalah peningkatan penanaman modal untuk mengolah potensi ekonomi menjadi kekuatan ekonomi riil dengan menggunakan modal yang berasal dari dalam negeri maupun dari luar negeri dengan memperhatikan kebijakan penanaman modal harus selalu dalam kerangka mendasari ekonomi kerakyatan yang melibatkan pengembangan bagi usaha mikro, kecil, menengah, dan koperasi. $^{3}$

Evaluasi selama kurun waktu 10 tahun masa berlakunya UUPT, telah diidentifikasi beberapa ketentuan yang harus segera direspon untuk meningkatkan peringkat Ease of Doing Business (EoDB), antara lain terkait dengan kegiatan memulai usaha (starting a business), ${ }^{4}$ perlindungan investor minoritas (protecting minority investor), dan penyelesaian kepailitan (resolving insolvency).

Data berikut menunjukan peringkat EoDB negara Asia Tenggara:

1 Meningkatnya kesejahteraan masyarakat merupakan salah satu tujuan Negara Indonesia, penegasan atas hal tersebut terkandung dalam pembukaan UUD 1945 beserta seluruh pokok-pokok pikiran yang terkandung di dalam Batang Tubuh UUD yaitu bahwa negara hendak mewujudkan keadilan sosial bagi seluruh rakyat. Pengejawantahan prinsip-prinsip demokrasi ekonomi di Indonesia diterjemahkan dalam pasal 33 ayat (1) UUD 1945 yang berbunyi "Perekonomian disusun sebagai usaha bersama atas asas kekeluargaan". Pemakaian asas kekeluargaan sebagai bentuk demokrasi ekonomi Indonesia yang tidak berdasarkan atas individualisme, tetapi untuk mencapai kemakmuranbersama dan sebagai penegasan kedaulatan ekonomi bangsa Indonesia. (Jimly Asshiddiqie, Konsolidasi Naskah UUD 1945 Setelah Perubahan Keempat, (Jakarta: PSHTN FHUI, 2002), hlm. 56.

2 Indonesia, Undang-Undang tentang Perseroan Terbatas, Undang-Undang Nomor 40 Tahun 2007, Lembaran Negara Tahun2007 Nomor 106, Tambahan LembaranNegara Nomor 4756.

3 Majelis Permusyawaratan Rakyat Republik Indonesia, Ketetapan Majelis Permusyawaratan Rakyat Republik Indonesia tentang Politik Ekonomi dalam Rangka Demokrasi Ekonomi, TAP MPR RI Nomor XVI/MPR/1998.

4 Berdasarkan hasil survei Ease of Doing Business (EoDB) peringkat EoDB awal tahun 2017 dari hasil survei World Bank, Indonesia menempati peringkat ke-91 dari 190 negara di dunia "Peringkat Yang Dipublikasikan Oleh Bank Dunia", http://www.doingbusiness.org/rankings. (diakses 24 Mei 2017). 
Tabel 1 Data Peringkat Kemudahan Berusaha Negara Asia Tenggara

\begin{tabular}{lcccccccccc}
\hline \multirow{2}{*}{ Negara } & \multicolumn{10}{c}{ Peringkat } \\
\cline { 2 - 12 } & 2008 & 2009 & 2010 & 2011 & 2012 & 2013 & 2014 & 2015 & 2016 & 2017 \\
\hline Brunei & 78 & 88 & 96 & 112 & 83 & 79 & 59 & 101 & 84 & 72 \\
\hline Filipina & 133 & 140 & 144 & 148 & 136 & 138 & 108 & 95 & 103 & 99 \\
\hline Indonesia & 123 & 129 & 122 & 121 & 129 & 128 & 120 & 114 & 106 & 91 \\
\hline Kamboja & 145 & 135 & 145 & 147 & 138 & 133 & 137 & 135 & 127 & 131 \\
\hline Laos & 164 & 165 & 167 & 171 & 165 & 163 & 159 & 148 & 134 & 139 \\
\hline Malaysia & 24 & 20 & 23 & 21 & 18 & 12 & 6 & 18 & 18 & 23 \\
\hline Myanmar & - & - & - & - & - & - & - & 177 & 167 & 170 \\
\hline Thailand & 15 & 13 & 12 & 19 & 17 & 18 & 18 & 26 & 49 & 46 \\
\hline TimorLeste & 168 & 170 & 164 & 174 & 168 & 169 & 172 & 172 & 173 & 175 \\
\hline Singapura & 1 & 1 & 1 & 1 & 1 & 1 & 1 & 1 & 1 & 2 \\
\hline Vietnam & 91 & 92 & 93 & 78 & 98 & 99 & 99 & 78 & 90 & 82 \\
\hline Sumber: & 172 &
\end{tabular}

Sumber : Doing Business ${ }^{5}$

Pada indikator starting a business, Indonesia dinilai sebagai negara dengan prosedur yang cukup banyak dan biaya yang cukup tinggi. Seperti yang dirilis oleh Bank Dunia pada awal tahun 2016, Indonesia di peringkat 173, karena harus melewati 13 prosedur dengan waktu 46 hari dan biaya yang besar, Malaysia di peringkat 14, karena cukup dengan 3 prosedur dan waktu selama 4 haril. Sementara Singapura ada di peringkat 10. Prosedurnya sama dengan Malaysia, namun lebih singkat, karena cukup selama 2 hari. ${ }^{6}$ Terkait dengan prosedur pendirian badan hukum PT, memberikan kontribusi 5 (lima) prosedur dari 11 (sebelas) prosedur memulai berusaha. ${ }^{7}$ Diantara Negara
ASEAN, Indonesia memiliki prosedur terbanyak dan waktu penyelesaian yang relatif terlama. Seperti data indikator Starting a Business yang dilansir Bank Dunia pada Juni 2017, Indonesia berada di peringkat 144, sementara Singapore di peringkat 6 , Thailand di peringkat 36 , Brunei Darussalam diperingkat58, Malaysia di peringkat 111, dan Bangladesh di peringkat $131 .^{8} \mathrm{Hal}$ ini menyebabkan daya saing masyarakat Indonesia dari sisi aspek legalitas usaha, lebih rendah pada Masyarakat Ekonomi ASEAN (MEA).

Dari sisi indikator protecting minority investor, menurut La Porta, perlindungan investor di negara code law lebih rendah dibandingkan di negara common law. Namun

Ibid.

6 "Kemudahan Berusaha Singapura no.1, Malaysia no.18 RI no.109", https://finance.detik.com/berita-ekonomibisnis/3123324/

7 Lima prosedur yang dimaksud adalah pesan nama perusahaan, persetujuan penggunaan nama, membuat akta pendirian perusahaan, dan pengesahan akta oleh Menteri Hukum dan Hak Asasi Manusia serta pembayaran penerimaan Negara bukan pajak untuk layanan hukum di bank.

$8 \quad$ Ease of Doing Business Rank 2017, Op.cit. 
perangkat hukum di Indonesia telah berusaha untuk melindungi pemegang saham minoritas melalui pre-emptive right. Hal ini tercermin pada pasal 43 UU PT, dimana pemegang saham mempunyai hak penawaran terlebih dahulu atas penambahan modal baru. Hal ini bertujuan untuk mencegah dilusi bagi para pemegang saham yang sudah ada. Kemudian terkait indikator resolving insolvency, UUPT tidak mengatur penyelamatan masalah kepailitan melainkan mengatur masalah pembubaran dan likuidasi.

Pada sisi yang lain dengan terbitnya UU Penanaman Modal telah memberikan harapan dalam iklim investasi di Indonesia. Disebut demikian karena berbagai pihak menyebut undang-undang penanaman modal cukup kompetitif. Dengan kata lain, berbagai fasilitas yang diberikan kepada investor dalam rangka melakukan investasi cukup menarik. Artinya UU Penanaman Modal dapat dibandingkan (comparable) dengan ketentuan penanaman modal Negara lain. ${ }^{9}$ Dengan diberlakukannya UU Penanaman Modal telah banyak perubahan yang terjadi antara lain permohonan penanaman modal diajukan melalui Pelayanan Terpadu Satu Pintu (PTSP) di bawah koordinasi BPKM.

Di luar dari pengaturan normatif kedua undang-undang di atas, permasalahan juga muncul terkait proses perizinan. Saat ini hampir semua kementerian sektoral berwenang menetapkan perizinan baik yang bersifat teknis maupun perizinan usaha seperti regulasi tentang pendirian PT, regulasi dasar agraria, regulasi terkait kelistrikan, pertambangan, perpajakan, pemerintahan daerah, dan lainnya. Hal tersebut dapat membuat peraturan menjadi tumpang tindih, inkonsistensi dan menimbulkan kebingungan. Beberap aturan yang dimaksud adalah seperti Permendag Nomor 36 Tahun 2007, Permendag Nomor 39 Tahun 2011, Permendag Nomor 37 Tahun 2007, Permendag Nomor 77 Tahun 2013 yang berkaitan dengan penerbitan SIUP dan TDP. Penerbitan SIUP dan TDP memiliki persyaratan dan fungsi izin yang relatif sama dan dapat disatukan. Selain itu perlu dilihat juga Permendagri Nomor 27 Tahun 2009 tentang Pedoman Penetapan Ijin Gangguan di Daerah di mana sebetulnya Surat izin tanda usaha (SITU) sudah termasuk dalam Izin Lingkungan seperti Amdal, UKL/UPL, SPPL.

Dari uraian di atas maka tulisan ini akan membahas beberapa peraturan perundangundangan yang mengatur kegiatan berusaha di Indonesia dan implikasinya terhadap perubahan modal dasar PT. Kemudian bagaimana upaya Pemerintah dan peran strategis Kementerian Hukum dan HAM RI dalam mendukung kemudahan berusaha.

\section{B. Metode Penelitian}

Berdasarkan permasalahan dan latar belakang yang diteliti, maka metode penelitian ini menggunakan metode hukum normatif yang bersifat deskriptif dengan pendekatan undangundang dan pendekatan kasus (case approach) ${ }^{10}$. Pendekatan undang-undang dilakukan dengan menelaah peraturan perundang-undangan yang berkaitan dengan kemudahan berusaha, antara lain Undang-Undang Nomor 40 Tahun 2007 tentang Perseroan Terbatas; Undang-undang Nomor 25 Tahun 2007 tentang Penanaman Modal; Undang-Undang Nomor 1 Tahun 2013 
tentang Lembaga Keuangan Mikro; UndangUndang Nomor 20 Tahun 2008 tentang Usaha Mikro, Kecil dan Menengah; Undang-Undang Nomor 3 Tahun 1982 tentang Wajib Daftar Perusahaan; dan Undang-Undang Nomor 37 Tahun 2004 Tentang Kepailitan dan Penundaan Kewajiban Pembayaran Utang dan kemudian meneliti bahan pustaka terkait. ${ }^{11}$ Tahap pertama penelitian hukum normatif dengan mengadakan penelitian terhadap masalah hukum dan tahap kedua ditujukan untuk mendapatkan hukum subjektif (hak dan kewajiban). ${ }^{12}$

\section{Pembahasan}

\section{Beberapa Peraturan Perundang- Undangan Terkait Dengan Kegiatan Berusaha Di Indonesia.}

a. Undang-Undang Nomor 40 tahun 2007 Tentang Perseroan Terbatas (UUPT).

UU PT merupakan salah satu pilar yang memberikan landasan bagi dunia usaha dan perekonomian nasional dalam menghadapi perkembangan perekonomian dunia di era globalisasi. Meski telah ada berbagai penyempurnaan sejak tahun 2007, tetapi masih terdapat permasalahan terkait dengan identitas PT sebagai sebuah badan hukum serta permasalahan lain terkait dengan proses pendiriannya. ${ }^{13}$ Selain itu, PT juga merupakan bentuk kegiatan ekonomi yang sangat disukai saat ini, karena pertanggungjawabannya yang hanya bersifat terbatas dari saham yang dimilikinya. PT juga memberikan kemudahan bagi pemilik (pemegang sahamnya) untuk mengalihkan kepada setiap orang dengan menjual seluruh saham yang dimiliki pada perusahaan tersebut. ${ }^{14}$

UU PT dianggap menghalangi atau menghambat kemudahan berusaha. Terutama yang berkaitan dengan modal setor. Struktur permodalan perseroan terbatas terdiri dari modal dasar, modal ditempatkan, dan modal disetor. Modal disetor harus ada dan menjadi bagian penting dari syarat untuk mendapatkan keputusan Menteri tentang pengesahan pendirian perseroan. Sehingga perlu merevisi dengan menghapus modal disetor. Perubahan UU PT dilakukan guna mendukung kemudahan berusaha.

b. Undang-Undang Nomor 25 Tahun 2007 Tentang Penanaman Modal (UndangUndang Penanaman Modal)

Hal lain yang merupakan keterkaitan antara Undang-Undang Penanaman Modal dengan UU PT adalah tentang modal. Mengacu Pasal 25 ayat (2) dan ayat (3) Undang-Undang Penanaman Modal, pengesahan pendirian badan usaha penanaman modal dalam negeri yang berbentuk badan hukum dan badan usaha penanaman modal asing yang berbentuk PT dilakukan sesuai dengan ketentuan peraturan perundang-undangan.

Peraturan perundang-undangan di bidang penanaman modal mengenal juga istilah modal (modal ditempatkan dan modal disetor),

11 Lihat lebih jauh dalam Soerjono Soekanto dan Sri Mamudji, Penelitian Hukum Normatif Suatu Tinjauan Singkat, Cetakan ke-11. (Jakarta: PT Raja Grafindo Persada, 2009), hlm. 13-14.

12 Hardijan Rusli, "Metode Penelitian Hukum Normatif: Bagaimana?", Law Review Fakultas Hukum Universitas Pelita Harapan Volume V No. 3 (2006): 50.

13 Herlien Budiyono, "Arah Pengaturan Undang-undang Nomor 40 Tahun 2007 tentang Perseroan Terbatas dalam Menghadapi Era Global", Jurnal Rechtsvinding Media Pembinaan Hukum Nasional (2012).

14 Ahmad Yani, dkk., Seri Hukum Bisnis Perseroan Terbatas. (Jakarta: PT. Raja Grafindo Persada, 2000), hlm. 7. 
meskipun izin usaha bukan bagian dari tahapan pendirian badan hukum PT. Hal ini bisa terlihat ketika penanam modal asing yang mengajukan izin usaha di Indonesia, harus memenuhi persyaratan besaran nilai modal ditempatkan dan modal disetor.

Dengan memberlakukan ketiadaan struktur modal dalam pendirian PT (baik modal dasar maupun modal yang harus ditempatkan dan disetor penuh), maka pengaturan struktur modal yang diatur dalam peraturan perundangundangan di bidang penanaman modal perlu dipertimbangkan kembali. Akan tetapi, terhadap jumlah minimum modal untuk badan usaha penanaman modal dalam negeri dan asing bisa ditentukan lebih besar dari pada ketentuan yang diatur dalam UU PT.

c. Undang-Undang Nomor 1 Tahun 2013 tentang Lembaga Keuangan Mikro (Undang-Undang Lembaga Keuangan Mikro)

Lembaga Keuangan Mikro (LKM) adalah lembaga keuangan yang khusus didirikan untuk memberikan jasa pengembangan usaha dan pemberdayaan masyarakat, baik melalui pinjaman atau pembiayaan dalam usaha skala mikro kepada anggota dan masyarakat, pengelolaan simpanan, maupun pemberian jasa konsultasi pengembangan usaha yang tidak semata-mata mencari keuntungan (Pasal 1 angka 1 Undang-Undang Lembaga Keuangan Mikro). Bentuk badan hukum LKM dapat berupa PT atau koperasi (Pasal 5 ayat (1) UndangUndang Lembaga Keuangan Mikro).

Dari sisi permodalan, modal LKM terdiri dari modal disetor untuk yang berbadan hukum PT, dan simpanan pokok, setoran wajib dan hibah bagi yang berbadan hukum koperasi. Untuk menjadi LKM yang cakupan usahanya berada di kabupaten maupun kota harus memiliki modal disetor minimum Rp500.000.000,00 (lima ratus juta rupiah). Untuk LKM yang cakupan usahanya di kecamatan, modal disetornya minimum Rp100.000.000,00 (seratus juta rupiah), sedangkan yang di desa atau kelurahan, modal yang disetor sebesar Rp50.000.000,00 (lima puluh juta rupiah).

Dengan memberlakukan ketiadaan struktur modal dalam pendirian PT (baik modal dasar maupun modal yang harus ditempatkan dan disetor penuh), maka pengaturan struktur modal yang diatur dalam peraturan perundangundangan di bidang LKM, perlu dipertimbangkan kembali. Selain itu, juga perlu dipertimbangkan jumlah minimum modal (disetor) untuk LKM. Hal tersebut didasarkan bahwa dasar pembentukan LKM yang berbentuk badan hukum PT, adalah untuk pemberdayaan masyarakat dalam usaha skala mikro dan tidak semata-mata untuk mencari keuntungan.

Pasal 4 Undang-Undang LKM, disebutkan bahwa pendirian LKM paling sedikit harus memenuhi persyaratan berbadan hukum, permodalan dan mendapat izin usaha yang tata caranya diatur dalam Undang-Undang ini. Selanjutnya pada Pasal 5, disebutkan bahwa bentuk badan hukum yang dimaksud dalam Pasal 4 tersebut harus memenuhi persyaratan pelaksana LKM harus berbadan hukum yaitu koperasi (harus jenis koperasi jasa bukan KSP) dan PT (Perseroan Terbatas), yang sahamnya harus dimiliki pemerintah daerah kab/kota sebesar $60 \%$ sisanya bisa milik perorangan WNI atau lembaga koperasi.

Berdasarkan ketentuan Pasal 5 tersebut, bahwa secara yuridis yang berbadan hukum koperasi dengan sendirinya akan berada di bawah dua macam perundangan yaitu UU Koperasi dan UU LKM. Dualisme pengaturan 
hukum ini berimplikasi pada terjadinya tumpang tindih kewenangan, inkonsistensi dan kontradiksi dalam pengaturan, pengawasan dan pembinaan terhadap Koperasi.

Pasal 9 ayat (1) dan (2) Undang-Undang LKM, bahwa sebelum menjalankan kegiatannya LKM harus memperoleh ijin dari OJK dengan memenuhi persyaratan paling sedikit meliputi susunan organisasi dan kepengurusan, kepemilikan, permodalan dan kelayakan rencana kerja. Kemudian pada Pasal 10 disebutkan bahwa pengaturan lebih lanjut melalui Peraturan OJK (POJK), membuat LKM berbadan hukum koperasi, bukan hanya harus tunduk pada Kementerian Koperasi dan membuat kondisi yang kurang relevan pada praktek di lapangan serta terkesan tumpang tindih peraturan, adanya aturan yang mengatur mengenai Koperasi yaitu Undang-Undang No. 17 Tahun 2012 Tentang Koperasi yang tentunya jauh lebih rinci mengatur mengenai Koperasi yang berasaskan kekeluargaan. Tampak dalam hal pendiriannya, semangat mempermudah pendirian koperasi justru terkesan menjadi semakin rumit dan tidak berpihak pada masyarakat kecil yang hanya menginginkan suatu lembaga keuangan yang simpel dan tidak terlalu rumit. Sehingga membuat adanya kecenderungan suatu peraturan menjadi tidak dilaksanakan di masyarakat.

d. Undang-Undang Nomor 20 Tahun 2008 tentang Usaha Mikro, Kecil dan Menengah (Undang-Undang UMKM)

Pemberdayaan Usaha Mikro, Kecil, dan Menengah perlu diselenggarakan secara menyeluruh, optimal, dan berkesinambungan melalui pengembangan iklim yang kondusif, pemberian kesempatan berusaha, dukungan, perlindungan, dan pengembangan usaha seluas-luasnya, sehingga mampu meningkatkan kedudukan, peran, dan potensi Usaha Mikro, Kecil, dan Menengah dalam mewujudkan pertumbuhan ekonomi, pemerataan dan peningkatan pendapatan rakyat, penciptaan lapangan kerja, dan pengentasan kemiskinan.

Undang-undang UMKM tidak hanya mengklasifikasikan jenis-jenis usaha yang ada di tanah air, akan tetapi juga mengatur tentang aspek penumbuhan iklim usaha yang ada di Indonesia berupa pendanaan, sarana dan prasarana, informasi usaha, kemitraan, perizinan usaha, kesempatan berusaha, promosi dagang dan dukungan kelembagaan. Hal tersebut ditujukan untuk memudahkan para pelaku usaha yang bergerak pada sektor Mikro, Kecil dan Menengah. Seperti yang terdapat pada pasal 8, 9 dan 10 pada bab 5 Undang-Undang UMKM, para pelaku usaha mendapatkan bantuan dari pemerintah di berbagai aspek antara lain aspek pendanaan dan juga aspek sarana prasarana.

e. Undang-Undang Nomor 3 Tahun 1982 tentang Wajib Daftar Perusahaan (Undang-Undang Wajib Daftar Perusahaan)

Setiap perusahaan wajib didaftarkan dalam daftar perusahaan (Pasal 5 UndangUndang Wajib Daftar Perusahaan). Perusahaan yang dimaksud itu berbentuk badan hukum, termasuk di dalamnya koperasi, persekutuan, perseorangan, dan perusahaan lainnya. Bahkan PT yang belum memperoleh pengesahan sebagai badan hukum tetapi sudah melakukan kegiatan usaha pun tidak luput dari kewajiban mendaftarkan perusahaannya (Pasal 11 ayat (1) huruf $h$ Undang-Undang Wajib Daftar Perusahaan). Untuk perusahaan yang berbentuk PT, hal-hal yang wajib didaftarkan sesuai yang 
terdapat pada Pasal 11 Undang-Undang Wajib Daftar Perusahaan ini.

Daftar Perusahaan untuk mencatat keterangan yang dibuat secara benar dari suatu perusahaan dan merupakan sumber informasi resmi untuk semua pihak yang berkepentingan mengenai identitas, data, serta keterangan lainnya tentang perusahaan yang tercantum dalam Daftar Perusahaan dalam rangka menjamin kepastian berusaha (Pasal 2). Daftar Perusahaan bersifat terbuka untuk semua pihak yang berarti bahwa Daftar Perusahaan itu dapat dipergunakan oleh pihak ketiga sebagai sumber informasi (Pasal 3). Setiap orang yang berkepentingan dapat memperoleh salinan atau petikan resmi dari keterangan yang tercantum dalam Daftar Perusahaan tertentu, setelah membayar biaya administrasi yang ditetapkan oleh Menteri Perdagangan.

f. Undang-undang Nomor 37 Tahun 2004 tentang Kepailitan dan Penundaan Kewajiban Pembayaran Utang (UU Kepailitan dan PKPU)

UU Kepailitan dan PKPU merupakan paket perundang-undangan yang dibuat untuk mengatasi krisis moneter. Implementasi UU Kepailitan dan PKPU tak semudah yang dibayangkan. Substansi UU Kepailitan dan PKPU bertentangan dengan hakekat dari hukum kepailitan. UU Kepailitan seolah menjadi mesin pembunuh bagi kelanjutan usaha dari debitor.

Pasal 2 ayat (1) UU Kepailitan menegaskan pailit bisa dimohonkan jika memenuhi dua syarat: debitor mempunyai dua kreditor atau lebih dan debitor tidak membayar sedikitnya satu utang yang telah jatuh tempo dan dapat ditagih. Pasal ini, menjadi bukti bahwa UU Kepailitan bertentangan dengan hakekat dibutuhkan upaya hukum kepailitan yang seharusnya untuk kepentingan seluruh kreditor. Pada implementasinya dapat timbul masalah ketika kreditor lain yang bukan pemohon pailit dan tagihannya sudah jatuh tempo atau belum jatuh tempo tidak berniat untuk melakukan tindakan hukum (mempailitkan debitor). Akibatnya para kreditor lain terpaksa ikut mendaftar sebagai kreditor.

Syarat minimum jumlah kreditor sebagai pemohon pailit seharusnya ditambah. Syarat debitor dapat dipailitkan juga harus memenuhi bukti bahwa minimum 75 persen kreditor memiliki utang dan sudah jatuh tempo, plus tidak dibayar. Debitor juga dibebani untuk membuktikan bahwa minimum 75 persen kreditor memiliki piutang yang sudah jatuh tempo. Jika hanya ada satu kreditor, perkara tersebut bisa diselesaikan melalui jalur gugatan perdata biasa atau permohonan eksekusi jaminan dengan syarat ada perbaikan proses perkara perdata dari sisi waktu.

Tingginya syarat perhitungan suara dan harus dipenuhi syarat kumulatif voting kreditor konkuren dan kreditor separatis yang diatur dalam Pasal 281 UU Kepailitan dan PKPU, menjadi penghambat utama proposal perdamaian yang diajukan oleh debitor sering mengalami kekalahan. Pasal 281 UU Kepailitan dan PKPU perlu direvisi menjadi kreditor separatis tidak berhak ikut serta dalam voting kecuali setuju menjadi kreditor konkuren seperti dulu berlaku di Perppu No. 1 Tahun 1998. Selain itu perlu dilakukan revisi yang menegaskan bahwa PKPU tak boleh diajukan oleh kreditor dan hanya dapat diajukan oleh debitor secara voluntary. Namun jika dengan segala pertimbangan kreditor dimungkinkan untuk mengajukan PKPU maka putusan PKPU harus membuka peluang kasasi bagi debitor. 


\section{Implikasi Perubahan Modal Dasar PT dan Kaitannya dengan Kemudahan Berusaha.}

Pemerintah sejak tanggal 21 Maret 2016 telah menerbitkan Peraturan Pemerintah (PP) Nomor 7 Tahun 2016 tentang Perubahan Modal Dasar PT. PP ini berisi tentang kebijakan untuk meningkatkan kemudahan berusaha bagi usaha mikro, kecil, dan menengah (UMKM), serta untuk melaksanakan ketentuan Pasal 32 Ayat (3) UUPT.

Dalam pasal 32 ayat 1 UUPT disebutkan adanya penekanan terhadap angka Rp50.000.000,00 (lima puluh juta rupiah) mengenai aturan modal dasar minimal dalam pendirian suatu PT, sehingga tidak mudah bagi pelaku usaha dalam negeri membentuk badan hukum PT dengan modal dasar kurang dari Rp 50 juta. Pengaturan mengenai PT ini memperlambat peningkatan pembangunan ekonomi nasional dan iklim investasi serta kemudahan berusaha.

Namun, pada pasal 32 ayat 3 disebutkan modal dasar tergantung keadaan ekonomi. Atas dasar ini, berkaitan dengan ketentuan modal dasar dituangkan dalam PP Nomor 7 Tahun 2016 tujuannya agar memberikan kemudahan pendirian PT bagi perusahaan rintisan (start up company). Sehingga pelaku usaha yang akan melakukan usaha tidak terbentur oleh persyaratan keharusan memiliki modal dasar yang begitu besar.

\section{a. Modal Dasar Pendirian PT.}

Modal dasar PT paling sedikit Rp50.000.000,00 (lima puluh juta rupiah) dimana salah satu atau seluruh pihak pendiri PT memiliki kekayaan bersih sesuai dengan kriteria UMKM. Modal dasar tersebut ditentukan berdasarkan kesepakatan para pendiri PT yang dituangkan dalam akta pendirian PT (pasal 1 ayat 2). Ketentuan di pasal 1 ayat 2 ini dimaksudkan untuk mengubah besaran Modal dasar sebagaimana diatur dalam UUPT yang semula ditentukan paling sedikit Rp50.000.000,00 (lima puluh juta rupiah) menjadi diserahkan pada kesepakatan para pendiri PT.

Dalam praktik pendirian PT selama ini, 'kekayaan bersih' dalam UU Nomor 20 tahun 2008 disederhanakan sebagai "modal dasar", sebenarnya keduanya merupakan hal yang berbeda. Apalagi dalam UU Nomor 20 tahun 2008 ada catatan tambahan yaitu 'tidak termasuk tanah dan bangunan tempat usaha' padahal hal ini bisa jadi merupakan kekayaan perseroan yang utama. Dalam penjelasan UU Nomor 20 tahun 2008 yang dimaksud dengan "kekayaan bersih" adalah hasil pengurangan total nilai kekayaan usaha (aset) dengan total nilai kewajiban, tidak termasuk tanah dan bangunan tempat usaha.

Bila dikaitkan dengan PP Nomor 7 tahun 2016 pasal 1 ayat 2, kemudahan yang dimungkinkan dapat saja kekayaan bersih suatu PT dengan kriteria Usaha Mikro ditentukan lebih kecil dari Rp 12,5 juta dan modal dasar kurang dari Rp 50 juta, misalnya hanya Rp 10 juta, sepanjang hal tersebut merupakan "kesepakatan para pendiri" PT tersebut.

b. Kewajiban Menyerahkan Bukti Setor.

PP Nomor 7 Tahun 2016 Pasal 2 menyebutkan bahwa modal dasar PT tersebut paling sedikit $25 \%$ (dua puluh lima persen) harus ditempatkan dan disetor penuh yang dibuktikan dengan bukti penyetoran yang sah. Bukti penyetoran yang sah wajib disampaikan secara elektronik kepada Menteri dalam waktu paling lama 60 (enam puluh) hari terhitung sejak tanggal akta pendirian PT ditandatangani. 
Adanya kebijakan bukti setor ini dapat menjawab permasalahan dalam praktik banyak PT yang didirikan secara fakta tidak memasukkan setoran modal karena dimudahkan dari prosedur yang cukup membuat surat pernyataan modal saja. Dengan adanya kebijakan ini, maka ke depannya akan ada kewajiban tambahan yang bersifat mengikat kepada pendirian PT untuk menyampaikan bukti penyetoran kepada Kementerian Hukum dan HAM secara elektronik.

Pembuatan akta pendirian PT tidak terlepas dengan peran notaris. Walaupun dengan adanya kewajiban menyetor dalam waktu 60 (enam puluh) hari setelah akta pendirian ini tidak berarti notaris harus "mengejar" klien yang sudah mendirikan PT melaluinya, agar menyerahkan bukti setor. Atau harus menahan salinan akta sampai yang bersangkutan menyerahkan bukti setornya dalam waktu 60 (enam puluh) hari. Hal ini tidak perlu dilakukan, karena biasanya setelah pendirian belum tentu klien tersebut terus berhubungan dengan notaris yang bersangkutan. Karena semua berpulang pada para pendiri/pemegang saham dari PT yang bersangkutan. Jika mereka tidak segera menyetorkan modal yang sudah dinyatakan di dalam akta pendirian PT mereka, maka PT tersebut tidak bisa memproses perubahan lain ke depannya, seperti : perubahan anggaran dasar, perubahan modal atau bahkan perpanjangan atau perubahan susunan direksi dan komisaris PT-nya.

Kewajiban menyerahkan bukti setor ini dapat dipahami seperti halnya Undang-Undang atau peraturan lainnya, tentunya tidak akan berlaku surut. Dengan demikian, kewajiban penyerahan bukti setor dalam waktu 60 (enam puluh) hari tersebut dikhususkan pada PT yang didirikan setelah tanggal 21 Maret 2016.

Sementara untuk PT yang sudah berdiri atau PT yang permohonannya sedang diproses pada saat PP Nomor 7 tahun 2016 diterbitkan, modal dasar sesuai ketentuan dalam Pasal 32 ayat (1) UUPT, tetap dapat menjalankan usahanya tanpa harus menyesuaikan modal dasarnya. Sedangkan permohonan pengesahan badan hukum PT yang sedang diproses, tetap diproses berdasarkan UUPT. Dengan terbitnya PP Nomor 7 Tahun 2016 diharapkan dapat memberikan kemudahan berusaha dan lebih menjamin ketertiban dunia usaha dalam investasi dengan mengubah besaran modal dasar yang dirasakan masih memberatkan bagi para pengusaha pemula.

\section{Upaya Pemerintah dan Peran Strategis Kementerian Hukum dan HAM RI dalam Mendukung Kemudahan Berusaha}

a. Upaya Pemerintah untuk Perbaikan Kemudahan Berusaha

Untuk mendukung kemudahan berusaha, pada Rencana Pembangunan Jangka Menengah Nasional (RPJMN) Tahun 2015-2019 dilakukan penurunan prosedur untuk memulai usaha menjadi 7 hari dan 5 prosedur untuk mencapai target peringkat ke-40 EoDB. ${ }^{15}$ Kebijakan yang telah dikeluarkan oleh Pemerintah Indonesia akhir-akhir ini adalah untuk memberikan gairah atau dorongan para investor untuk menanamkan modalnya. Intervensi pemerintah terhadap investasi terutama pada instrumen perizinan.

Bank Dunia menetapkan 10 indikator tingkat kemudahan berusaha yaitu: memulai 
usaha (starting a business), perizinan terkait pendirian bangunan (dealing with construction permit), pembayaran pajak (paying taxes), akses perkreditan (gettingcredit), penegakan kontrak (enforcing contract), penyambungan listrik (getting electricity), perdagangan lintas negara (trading across borders), penyelesaian perkara kepailitan (resolving insolvency), dan perlindungan terhadap investor minoritas (protecting minority investors).

Pada tahun 2016, total jumlah prosedur kemudahanan berusaha (10 indikator) yang sebelumnya berjumlah 94 prosedur, telah dipangkas menjadi 49 prosedur. Begitu pula perizinan yang sebelumnya berjumlah 9 izin, dipotong menjadi 6 izin. Jika sebelumnya waktu yang dibutuhkan total berjumlah 1,566 hari, kini dipersingkat menjadi 132 hari. Perhitungan total waktu ini belum menghitung jumlah hari dan biaya perkara pada indikator resolving insolvency karena belum ada praktik dari peraturan yang baru diterbitkan. ${ }^{16}$

Salah satu Indikator EoDB yaitu memulai usaha (starting a business). Indikator ini diyakini sangat mempengaruhi indikator lainnya. Adapun prosedur memulai usaha adalah pembayaran pesan nama perusahaan, pesetujuan penggunaan nama, akte pendirian perusahaan, pengesahan akte oleh Menkumham, pembayaran PNBP pendirian perusahaan, Surat Keterangan Domisili Usaha (SKDU), Surat Izin Usaha Perdagangan (SIUP) dan Tanda Daftar Perusahaan (TDP), wajib lapor ketenagakerjaan, pendaftaran Badan
Penyelenggara Jaminan Sosial (BPJS) kesehatan, pendaftaran BPJS ketenagakerjaan, serta Nomor Pokok Wajib Pajak (NPWP) dan Nomor Pengukuhan Pengusaha Kena Pajak (NPPKP). ${ }^{17}$

Pemerintah untuk mendukung kemudahan berusaha harus membentuk tim kemudahan berusaha, baik di tingkat pusat maupun daerah. Selain itu, pemerintah juga harus membentuk tim koordinasi antar instansi terkait. Secara regulasi pemerintah harus merevisi peraturan peraturan yang tumpang tindih dan peraturan yang menghambat kemudahan untuk berusaha. Namun demikian, pemerintah juga harus melakukan pengawasan dan pengendalian terhadap pelaksanaan pelayanan dalam dunia usaha.

Peringkat EoDB Indonesia, sebagaimana survei Bank Dunia, pada peringkat ke-106 dari 190 negara yang disurvei di awal tahun 2016. Indonesia terus berusaha memperbaiki peringkat kemudahan berbisnis. Peringkat EoDB Indonesia terkoreksi Bank Dunia dari peringkat ke-106 naik menjadi peringkat ke-91 pada awal tahun 2017. Adanya perbaikan peringkat menunjukkan bahwa semua pihak sudah bekerja ekstra keras memperbaiki peringkat kemudahan berusaha Indonesia. ${ }^{18}$

Pemerintah Indonesia telah melakukan sejumlah perbaikan, baik dari aspek peraturan maupun prosedur perizinan dan biaya, agar peringkat EoDB di Indonesia terutama bagi UMKM, semakin meningkat. Bahkan Pemerintah telah membentuk tim khusus untuk melakukan koordinasi dengan BKPM dan

16 Antara, "Paket Ekonomi XII Naikkan Peringkat Kemudahan Berusaha di Indonesia". http://www.antaranews. com/Berita/557836/. (diakses 25 Juni 2017).

17 EODB, "Starting a Business", http://eodb.ekon.go.id/indikator-eodb/starting-a-business/. (diakses 24 Juni 2017).

18 Suara Merdeka, "Indonesia Lima Besar Kekuatan Ekonomi Dunia“, berita.suaramerdeka.com. (diakses 12 Maret 2017). 
beberapa kementerian dan lembaga terkait. Demi mencapai target tersebut, pemerintah melibatkan 15 institusi Kementerian/Lembaga (K/L) dan dua pemerintah daerah untuk perbaikan menyeluruh 10 indikator kemudahan berusaha.

Untuk meningkatkan peringkat kemudahan berusaha, sejumlah perbaikan dilakukan pada seluruh indikator yang ada. Pada indikator memulai berusaha, misalnya, sebelumnya pelaku usaha harus melalui 13 prosedur yang memakan waktu 47 hari dengan biaya berkisar antara Rp 6,8 - 7,8 juta. Izin yang harus diurus meliputi SIUP, TDP, Akta Pendirian, Izin Tempat Usaha, dan Izin Gangguan. Kini pelaku usaha hanya akan melalui 7 prosedur selama 10 hari dengan biaya Rp 2,7 juta. ${ }^{19}$ Izin yang diperlukan bagi UMKM adalah SIUP dan TDP yang terbit bersamaan, dan akta pendirian.

Kemudahan lain yang diberikan kepada UMKM adalah persyaratan modal dasar pendirian perusahaan. Modal dasar untuk UMKM ditentukan berdasarkan kesepakatan para pendiri PT yang dituangkan dalam akta pendirian PT sesuai dengan pasal 1 ayat (2) PP Nomor 7 Tahun 2016 tentang Perubahan Modal Dasar PT. Begitu juga dengan perizinan yang terkait Pendirian Bangunan. Jika sebelumnya harus melewati 17 prosedur yang membutuhkan waktu 210 hari dengan biaya Rp 86 juta untuk mengurus 4 izin (Izin Mendirikan Bangunan (IMB), Upaya Pengelolaan Lingkungan(UKL), Sertifikat Laik Fungsi (SLF), Tanda Daftar Gudang (TDG)), kini hanya ada 14 prosedur dalam waktu 52 hari dengan biaya Rp 70 juta untuk 3 perizinan (IMB, UKL,SLF, TDG).
Demikian halnya dengan pembayaran pajak. Pembayaran pajak yang sebelumnya melalui 54 kali pembayaran, telah dipangkas menjadi hanya 10 kali pembayaran dengan sistem online. Sedangkan pendaftaran properti yang sebelumnya melewati 5 prosedur dalam waktu 25 hari dengan biaya 10,8\% dari nilai properti, menjadi 3 prosedur dalam waktu 7 hari dengan biaya $8,3 \%$ dari nilai properti/transaksi.

Dalam hal penegakan kontrak, dengan terbitnya Peraturan Mahkamah Agung Nomor 2 Tahun 2015 tentang Tata Cara Penyelesaian Gugatan Sederhana, maka untuk kasus gugatan sederhana diselesaikan melalui 8 prosedur dalam waktu 28 hari. Bila ada keberatan terhadap hasil putusan, masih dapat melakukan banding. Namun jumlah prosedurnya bertambah 3 prosedur, sehingga total menjadi 11 prosedur. Waktu penyelesaian banding ini maksimal 10 hari.

Berdasarkan Undang-undang Nomor 23 tahun 2014 tentang Pemerintahan Daerah, terkait Norma, Standar, Prosedur, dan Kriteria (NSPK) dibutuhkan koordinasi dengan kementerian teknis terkait. Untuk itu, Kemenko Perekonomian bersama dengan Kemendagri berkoordinasi dengan $\mathrm{K} / \mathrm{L}$ terkait untuk menyiapkan NSPK tersebut. Untuk hasil yang lebih optimal, perlu ada lembaga permanen yang fokus mengejar peringkat kemudahan berusaha.

BKPM telah bekerja sama dengan Asian Development Bank (ADB) serta Komite Pemantauan Pelaksanaan Otonomi Daerah (KPPOD) menggelar sosialiasi perbaikan kemudahan berusaha. Sosialisasi yang 
dilaksanakan berkaitan dengan penyederhanaan perizinan SIUP, TDP, wajib lapor ketenagakerjaan, BPJS kesehatan dan BPJS ketenagakerjaan yang diterbitkan dengan satu permohonan di Pelayanan Terpadu Satu Pintu (PTSP). Seperti yang telah dilaksanakan dengan baik di DKI Jakarta dan di Surabaya.

Penetapan target perbaikan kesepuluh indikator yang terukur penekanannya pada jumlah prosedur, waktu, dan biaya. Kemudahan yang sangat membantu pelaku usaha dalam negeri untuk membentuk badan hukum PT adalah sudah tidak adanya batas modal dasar minimal. ${ }^{20}$ Pemerintah melalui BKPM juga telah memetakan 22 peraturan yang terkait dengan kemudahan berusaha di pusat dan daerah, untuk direvisi atau dideregulasi. BKPM berkoordinasi dengan $\mathrm{K} / \mathrm{L}$ lainnya untuk memetakan peraturan serta menyusun rencana aksi. Secara lebih rinci, 22 peraturan itu diterbitkan oleh 11 kementerian dan instansi terkait lainnya. Identifikasi 22 peraturan itu mengacu kepada 10 indikator survei kemudahan berusaha yang disusun oleh Bank Dunia.

BKPM juga telah berkoordinasi dengan Kementerian Hukum dan HAM yang berkaitan dengan tiga indikator survei sekaligus, yakni indikator memulai usaha (starting $a$ business), indikator mendapatkan pinjaman (getting credit) terkait fidusia online, serta menyelesaikan kepailitan(resolving insolvency). Untuk memulai usaha misalnya, dilakukan penyederhanaan perizinan SIUP, TDP, Wajib Lapor ketenagakerjaan, BPJS kesehatan dan BPJS ketenagakerjaan. Perbaikan lainnya pada indikator membayar pajak (paying taxes), BKPM berkoordinasi dengan Direktorat Jenderal Pajak. Kemudahan yang diupayakan adalah fasilitas pembayaran dan pelaporan pajak dilakukan secara online sehingga memangkas waktu pembayaran.

Sementara perbaikanindikatormendapatkan kredit, melibatkan koordinasi dengan Bank Indonesia (BI) dan Otoritas Jasa Keuangan (OJK). Dua otoritas ini telah mengeluarkan dua izin usaha untuk lembaga pengelola informasi perkreditan, yaitu PT Pefindo Biro Kredit dan PT Kredit Biro Indonesia Jaya. Untuk indikator penegakan kontrak (enforcing contract), telah diatur oleh Peraturan Mahkamah Agung (MA) Nomor 2 Tahun 2015 tentang Tata Cara Penyelesaian Gugatan Sederhana. Aturan itu memuat ketentuan proses pendaftaran sampai sidang putusan adalah maksimal 25 hari kerja.

Perbaikan kemudahan berusaha diarahkan bukan hanya untuk mengejar peringkat EoDB, tetapi ditujukan untuk meningkatkan daya saing nasional dalam Masyarakat Ekonomi ASEAN dan produktivitas, penciptaan lapangan kerja, ekspor. BKPM bersama dengan $\mathrm{K} / \mathrm{L}$ terkait, dan dimonitor oleh Kementerian Koordinator Bidang Perekonomian, menyusun rencana aksi yang mencakup berbagai perbaikan di 10 indikator tersebut dengan hasil diterbitkannya peraturan perundang-undangan sebagai dasar hukum (legal basis) bagi setiap fokus area kemudahan berusaha, seperti yang terdapat pada tabel 2 berikut:

20 BKPM, "Sebagian Besar Deregulasi Perbaikan Kemudahan Berusaha Telah Diselesaikan”, Siaran Pers BKPM 22 Maret 2017, http://www2.bkpm.go.id. (diakses 20 Juni 2017). 
Tabel 2. Rencana Aksi Kemudahan Berusaha

\begin{tabular}{|c|c|c|}
\hline No. & Indikator & Rencana Aksi \\
\hline 1. & Starting a busniss & $\begin{array}{l}\text { Penghapusan persyaratan modal minimal untuk pendirian PT menjadi } \\
\text { diserahkan kepada para pihak, Sebelumnya dipersyaratkan modal minimal } \\
\text { Rp50juta untuk pendirian PT. }\end{array}$ \\
\hline 2. & $\begin{array}{l}\text { Dealing with } \\
\text { construction permit }\end{array}$ & $\begin{array}{l}\text { Tidak lagi dipersyaratkan UKL/UPL untuk bangunan tidak sederhana } 2 \\
\text { lantai. Sebelumnya dipersyaratkan dan tidak ada SOP yang jelas. }\end{array}$ \\
\hline 3. & Registering property & Pengecekan sertifikat tanah dalam 1 hari, sebelumnya 3 hari. \\
\hline 4. & Getting electricity & Permohonan secara online dalam 1 hari, sebelumnya 9 hari. \\
\hline 5. & Trading across borders & $\begin{array}{l}\text { Aplikasi online untuk ekspor dan impor melalui National Single Window } \\
\text { (NSW), sebelumnya dokumen diserahkansecara manual, 4dokumen } \\
\text { ekspordan } 8 \text { dokumen impor. }\end{array}$ \\
\hline 6. & $\begin{array}{l}\text { Protecting minority } \\
\text { investors }\end{array}$ & $\begin{array}{l}\text { Shareholder mendapatkan hak pertama kali untuk membeli saham } \\
\text { perusahaan. }\end{array}$ \\
\hline 7. & Resolving insolvency & $\begin{array}{l}\text { Biaya kurator sekarang berdasarkan \% dari nilai hutang atau tarif jam } \\
\text { terpakai, sebelumnya berdasarkan \% dari nilai aset. }\end{array}$ \\
\hline 8. & Getting credit & $\begin{array}{l}\text { Penerbitan } 2 \text { izin Lembaga Pengelola Informasi Perkreditan (LPIP) oleh OJK, } \\
\text { sebelumnya tidak terdapat LPIP dan saat ini telah terdapat PT Pefindo Biro } \\
\text { Kredit dan PT Kredit Biro Indonesia Jaya. }\end{array}$ \\
\hline 9. & Paying taxes & Pendaftaran dan pembayaran secara online untuk PPh Badan. \\
\hline 10. & Enforcing contract & $\begin{array}{l}\text { Prosedur yang jelas dan ringkas untuk pengadilan gugatan sederhana: } 8 \\
\text { prosedur, } 25 \text { hari bila tidak adabanding dan } 11 \text { prosedur, } 38 \text { hari bila ada } \\
\text { banding. Sebelumnya tidak ada prosedur yang jelas. }\end{array}$ \\
\hline
\end{tabular}

Sumber : Laporan BKPM ${ }^{1}$

Langkah memetakan perbaikan peraturan serta menyusun rencana aksi telah dilakukan. Semestinya implementasi dari perbaikan serta rencana aksi ini harus dikawal secara bersamasama. Dan perlu membentuk tim untuk membedah berbagai hambatan regulasi yang berkaitan dengan EoDB. Sebab dalam kegiatan berusaha justru regulasi sangat diperlukan, karena sumber-sumber ekonomi yang terbatas di satu pihak, dan tidak terbatasnya permintaan atau kebutuhan akan sumber ekonomi, di pihak lain akan memungkinkan terjadi konflik antar warga dalam memperebutkan sumbersumber ekonomi tersebut. ${ }^{21}$ Kebutuhan akan hukum yang dapat diprediksi dinilai penting bagi negeri yang sebagian besar rakyatnya, memasuki hubungan-hubungan ekonomi melampaui lingkungan sosial yang tradisional. Aspek keadilan, seperti perlakuan yang sama dan standar pola tingkah laku pemerintah, diperlukan untuk menjaga mekanisme pasar dan mencegah birokrasi yang berlebihan. ${ }^{22}$

21 Gunarto Suhardi. Peranan Hukum Dalam Pembangunan Ekonomi, (Yogyakarta: Universitas Atmajaya, 2002), hlm. 5 .

22 Leonard J. Theberge," Law and Economic Development", Journal of International Law and Politics, vol. 9 (1989), hlm. 232. 
b. Peran Strategis Kementerian Hukum dan HAM RI

Dalam menyikapi kemudahan berusaha Kemenkumham telah melakukan revolusi pelayanan. Wujud nyata yang dilakukan dengan melakukan pelayanan online, seperti pelayanan secara online Pendirian (PT, Yayasan dan Perkumpulan) dilakukan pelayanan dari 207, Perubahan (PT, Yayasan dan Perkumpulan) 30 hari, dan Pendaftaran Jaminan Fidusia dari 60 hari masing-masing pelayanan dapat selesai dalam waktu 7 menit. Sebab menurut Philip Kotler, internet (secara online) memberikan jalan yang begitu luas bagi pemasar untuk membangun hubungan dengan pelanggan. ${ }^{23}$ Namun demikian, hukum memerlukan dukungan personalia yang profesional dan beretika, organisasi yang kapabel dan berdaya guna, serta peradilan yang bebas dan berhasil guna. Semuanya ini adalah sebagian prasyarat konsepsional yang paling di butuhkan dalam konteks kekinian Indonesia. ${ }^{24}$ Sementara, peranan hukum adalah untuk melindungi, mengatur dan merencanakan kehidupan ekonomi sehingga dinamika kegiatan ekonomi itu dapat diarahkan kepada kemajuan dan kesejahteraan bagi seluruh masyarakat sebagaimana dikemukakan oleh Thomas Aquinas dalam Suma Theologica. ${ }^{25}$ Pada dasarnya setiap kegiatan atau aktivitas manusia perlu diatur oleh suatu instrumen yang disebut sebagai hukum. Hukum dalam hal ini direduksi pengertiannya menjadi perundang-undangan yang dibuat dan dilaksanakan oleh negara. ${ }^{26}$

Untuk mendukung kemudahan berusaha, sejak 25 Januari 2016 Kemenkumham telah menerbitkan Peraturan Menteri Hukum dan HAM (Permenkumham), yaitu Permenkumham Nomor 1 Tahun 2016 (PT), Permenkumham Nomor 2 Tahun 2016 (Yayasan), dan Permenkumham Nomor 3 Tahun 2016 (Perkumpulan). Permenkumham ini menyebutkan bahwa pemohon mengajukan permohonan pemakaian nama PT, Yayasan, dan Perkumpulan kepada Menteri melalui Sistem Administrasi Badan Hukum (SABH). $\mathrm{SABH}$ adalah jenis pelayanan jasa hukum yang memberikan kepada masyarakat dunia usaha dalam proses pengesahan badan hukum PT, pemberian persetujuan perubahan anggaran $\mathrm{PT}$, serta pemberitahuan informasi lainnya secara elektronik (melalui jaringan komputer dan internet), yang diselenggarakn oleh Direktorat Jenderal Administrasi Hukum Umum (Ditjen AHU) pada Kementerian Hukum dan HAM RI. ${ }^{27}$ $\mathrm{SABH}$ juga dianggap memenuhi karakteristik efisiensi dan efektivitas dalam proses legalisasi PT sehingga diharapkan mampu menjembatani dinamisme dunia usaha. Sistem baru tersebut masih tidak lepas dari peranan penting seorang notaris. ${ }^{28}$

\footnotetext{
23 Kotler, Philip, Manajemen Pemasaran, jilid dua, edisi millennium, (Jakarta: Penerbit PT Prenhallindo, 2002), hlm. 445.

24 Firoz Gaffar, ed., Reformasi Hukum di Indonesia, Cetakan keempat, (Jakarta: CYBERconsult, 2000), hlm. 1.

25 Gunarto Suhardi, Peranan Hukum Dalam Pembangunan Ekonomi, (Yogyakarta: Universitas Atmajaya, 2002), hlm. 12.

26 Hikmahanto Juwana, Bunga Rampai Hukum Ekonomi dan Hukum Internasional, (Jakarta: Lentera Hati, 2002), hlm. 27.

27 Hukum Perseroan Terbatas, "Permohonan Melalui Media Elektronik", http://www.hukumperseroanterbatas. com. (diakses 14 Mei 2017).

28 Direktorat Jenderal Aministrasi Hukum Umum, “Direktorat Jenderal Administrasi Hukum Umum Online”, http:// www.ahu.go.id. (diakses 22 Juni 2017).
} 
Sesuai dengan jargon "PASTI" (Propesional, Akuntabel, Sinergi, Transparan, Inovatif), Kemenkumham telah melakukan inovasi dalam mendukung EoDB. Implementasi inovasi itu merupakan upaya mendorong EoDB demi mendukung perekonomian nasional. Kemenkumham menentukan inovasi yang dilakukan sesuai peranan strategisnya yaitu mencakup tiga dari total sepuluh indikator dalam EoDB, yakni permulaan bisnis (starting business), penerimaan kredit (getting credit) dan penyelesaian kepailitan (resolving insolvency).

Inovasi penekanan biaya jasa hukum notaris termasuk termasuk salah satu dalam indikator permulaan bisnis. Terkait dengan indikator permulaan bisnis ini, Kemenkumham pada 31 Maret 2017 telah menerbitkan Permenkumham Nomor 3 Tahun 2017 Tentang Jasa Hukum Notaris Untuk Pendirian Perseroan Terbatas Bagi Usaha Mikro, Kecil dan Menengah(UMKM). Peraturan ini bertujuan untuk menekan biaya jasa hukum notaris dalam pendirian PT bagi UMKM. Dalam Permenkumham itu disebutkan, biaya jasa hukum notaris bagi UMKM dengan modal dasar paling banyak Rp25 juta hanya dikenai Rp 1 juta. Sementara, untuk UMKM bermodal dasar paling banyak Rp1 miliar, dikenakan Rp 5 juta.

Beberapa inovasi baru terhadap indikator permulaan bisnis yang telah dilakukan antara lain proses pemesanan nama PT hingga penerbitan Surat Keputusan (SK), perubahan modal dasar perseroan, serta penerapan tarif PNBP di lingkungan Kemenkum HAM ${ }^{29}$. Inovasi dalam penerimaan kredit yaitu layanan online untuk penerima fidusia, kuasa dan wakilnya dalam hitungan menit. Kemenkumham juga meluncurkan inisiatif penyempurnaan sistem pendaftaran jaminan fidusia online dengan meluncurkan akses korporat dan retail fidusia online, melengkapi akses notaris yang selama ini telah tersedia. Semua langkah-langkah penyederhanaan dan perbaikan layanan publik tersebut memiliki dampak nyata dalam meningkatkan EoBE serta transparansi proses perizinan dan nonperizinan yang harus dilalui oleh pengusaha untuk memulai dan menjalankan usaha. Peningkatan layanan publik melalui pemutakhiran portal AHU online telah mengubah secara revolusioner cara Direktorat Jenderal Administrasi Hukum Umum (Ditjen AHU) memberikan pelayanan publik. Saat ini, pemohon dapat mengakses layanan badan hukum dan pendaftaran jaminan fidusia kapanpun dan dimana pun untuk dirampungkan dalam hitungan menit.

Sementara inovasi dalam penyelesaian kepailitannya adalah pembaruan tarif kurator dalam Permenkumham Nomor 2 Tahun 2017 Tentang Imbalan Jasa Kurator dan Pengurus. Inovasi dalam getting credit adalah layanan online penerima Fidusia yang dapat di akses langsung oleh masyarakat, kuasa dan wakilnya dalam hitungan menit, selanjutnya resolving insolvency, yaitu dalam Permenkumham Nomor 2 Tahun 2017 tentang Perubahan atas Permenkumham Nomor 11 Tahun 2016 Tentang Imbalan Jasa Kurator dan Pengurus sebagai bentuk pembaruan dalam mengatasi permasalahan kepailitan. Kemenkumham secara terus-menerus dengan gencar mensosialisasikan reformasi peningkatan pelayanan publik di bidang pendaftaran dan perizinan usaha yang telah terselenggara dalam rangka peningkatan kemudahan berusaha bagi para pelaku UMKM 
di Indonesia. Sosialisasi dilakukan di hadapan para pelaku usaha, Asosiasi Pengusaha Indonesia (Apindo), perbankan dan pemangku kepentingan lainnya di pusat dan daerah.

Selain sosialisi secara langsung, Kemenkumham juga telah melaksanakan kegiatan sosialisasi EoDB melalui portal AHU online. Peningkatan layanan publik melalui pemutakhiran portal AHU online telah mengubah secara revolusioner memberikan pelayanan publik. Sosialisasi yang menyeluruh terkait AHU online yang berkaitan dengan EoBD yaitu materi pengesahan badan hukum perseroan online, Pengesahan Badan Hukum Yayasan online, dan pengesahan badan hukum perkumpulan online, fidusia online, dan pengangkatan notaris. Dengan kegiatan ini diharapkan masyarakat dapat mengetahui apa saja inovasi yang telah dilakukan agar selanjutnya saat survei EoDB dapat mengisi kuesioner sesuai dengan kebijakan yang telah dilaksanakan dan dapat mendorong tercapainya peningkatan Indonesia di peringkat ke-40 EoDB serta senantiasa memberikan manfaat bagi bangsa dan negara.

\section{Penutup}

Peraturan perundang-undangan atau kebijakan yang dikeluarkan oleh pemerintah telah memberikan dorongan kepada para investor untuk menanamkan modalnya. UU PT belum sepenuhnya mendukung kemudahan berinvestasi dan memperbaiki iklim berusaha di Indonesia. UU PT telah mendapat dukungan dari peraturan lainnya yang berkaitan dengan berusaha, seperti UU Penanaman Modal, UU Lembaga Keuangan Mikro, UU Usaha Mikro, Kecil dan Menengah, UU Wajib Daftar Perusahaan, dan UU Kepailitan dan Penundaan Kewajiban Pembayaran Utang.
UU PT dianggap menghalangi atau menghambat kemudahan berusaha. Terutama yang berkaitan dengan modal setor. UU PT mengamanatkan Modal disetor harus ada dan menjadi bagian penting dari syarat untuk mendapatkan keputusan menteri tentang pengesahan pendirian perseroan. Namun, untuk UU Penanaman Modal dianggap mendukung kemudahan berusaha di Indonesia. Ini terlihat pada kebijakan dalam UU Penanaman Modal dengan perlakuan sama kepada penanam modal, baik dari dalam maupun asing yang melakukan penanaman modal di Indonesia. Memberikan fasilitas terhadap penanam modal asing, antara lain pembebasan atau keringanan pajak, repatriasi modal, fasilitas perizinanan, dan penyerahan sengketa ke badan arbitrase internasional.

Sementara itu, UU LKM dapat memberdayaan masyarakat dalam berusaha. Namun, Pengaturan struktur modal yang diatur dalam peraturan perundang-undangan di bidang LKM, perlu dipertimbangkan kembali dan perlu dipertimbangkan jumlah minimum modal (disetor) untuk LKM. Hal tersebut didasarkan bahwa dasar pembentukan LKM yang berbentuk badan hukum PT adalah untuk pemberdayaan masyarakat dalam usaha skala mikro dan tidak semata-mata untuk mencari keuntungan. Kemudian, Undang-undang UMKM mengatur tentang aspek penumbuhan iklim usaha yang ada di indonesia berupa pendanaan, sarana dan prasarana, informasi usaha, kemitraan, perizinan usaha, kesempatan berusaha, promosi dagang dan dukungan kelembagaan, hal tersebut ditujukan untuk memudahkan para pelaku usaha yang bergerak pada sektor Mikro, Kecil dan Menengah.

Untuk UU Wajib Daftar Perusahaan sangat mendukung kemudahan berusaha. Daftar 
Perusahaan dimaksudkan untuk mencatat keterangan yang dibuat secara benar dari suatu perusahaan dan merupakan sumber informasi resmi untuk semua pihak yang berkepentingan mengenai identitas, data, serta keterangan lainnya tentang perusahaan yang tercantum dalam Daftar Perusahaan dalam rangka menjamin kepastian berusaha. Di sisi lain UU Kepailitan dan PKPU seolah menjadi mesin pembunuh bagi kelanjutan usaha dari debitor. UU Kepailitan dan PKPU perlu disinkronisasi dengan UU yang saling berkaitan seperti UU Perseroan Terbatas, UU tentang Larangan Praktek Monopoli dan Persaingan Usaha Tidak Sehat, dan UU Penanaman Modal. Kepailitan memang rentan untuk dipakai tidak benar, tetapi juga penting bagi perusahaan yang memang punya aset tapi tidak mau bayar.

PP Nomor 7 Tahun 2016 yang berisi tentang kebijakan pemerintah berimplikasi untuk meningkatkan kemudahan berusaha bagi usaha mikro, kecil, dan menengah (UMKM), serta untuk melaksanakan ketentuan Pasal 32 Ayat (3) UU PT saat ini yang menyebutkan modal dasar tergantung keadaan ekonomi. Realisasi indikator kemudahan berusaha telah dilakukan dengan memperkecil jumlah prosedur, mengurangi waktu pengurusan, dan mengurangi biaya dengan merevisi peraturan teknis di masing-masing kementerian dan lembaga terkait. Upaya Pemerintah berikutnya fokus pada penanaman modal dan perizinan terkait memulai berusaha, mekanisme, serta pengawasan dan pengendaliannya. Kepastian hukum dan kemudahan dalam mendirikan badan usaha, memberikan pengaruh yang signifikan terhadap investasi riil. Kemudahan berusaha yang ditunjang dengan penggunaan informasi dan teknologi, membuat proses pendaftaran pendirian PT menjadi lebih cepat, tercatat dalam sistem, efisien, dan sesuai dengan perkembangan masyarakat modern. Penggunaan informasi dan teknologi seperti revolusi layanan online yang dilakukan Kemenkumham dapat mengurangi kemungkinan korupsi dan pungutan liar. Kemenkumham dengan peran strategisnya telah menerbitkan Permenkumham mengenai tata cara pengajuan permohonan pengesahan persetujuan dan perubahan data PT, Yayasan, dan Perkumpulan melalui Sistem Administrasi Badan Hukum (SABH).

Untuk lebih meningkatkan kemudahan berusaha perlu segera merealisasikan perubahan UU PT serta mendorong pengaturan PT dan pengaturan kepailitan dalam undangundang yang baru, sehingga terjadi peningkatan investasi dan daya saing Indonesia. Selain itu, perlu merevisi dan membentuk peraturan yang lebih fokus kepada peraturan teknis dan melakukan penggabungkan izin-izin sektoral menjadi izin usaha yang diatur dalam Peraturan Presiden. Serta perlunya merealisasikan pembentukan lembaga permanen yang fokus mengejar peringkat kemudahan berusaha yang bertanggung jawab langsung kepada Presiden.

\section{Daftar Pustaka}

\section{Buku}

Asshiddiqie, Jimly, Konsolidasi Naskah UUD 1945 Setelah Perubahan Keempat (Jakarta: PSHTN FHUI, 2002)

Gaffar, Firoz ed., Reformasi Hukum di Indonesia, Cetakan keempat (Jakarta: CYBERconsult, 2000)

Juwana, Hikmahanto, Bunga Rampai Hukum Ekonomi dan Hukum Internasional (Jakarta: Lentera Hati, 2002)

Kotler, Philip, Manajemen Pemasaran, jilid dua, edisi millennium (Jakarta: Penerbit PT Prenhallindo, 2002)

Marzuki, Peter Mahmud, Penelitian Hukum (Jakarta: Kencana Prenada Media Group, 2009)

Sentosa Sembiring, Hukum Investasi, cetakan kedua (Bandung: CV. Nuansa Aulia, 2010) 
Soekanto, Soerjono, Pengantar Penelitian Hukum (Jakarta: UI Press, 1986)

Soekanto, Soerjono dan Sri Mamudji Penelitian Hukum Normatif Suatu Tinjauan Singkat, Cetakan ke-11 (Jakarta : PT Raja Grafindo Persada, 2009)

R.Soekardono, Hukum Dagang Indonesia, Jilid 1 (Bagian Kedua) (Jakarta: Rajawali, 1991)

Subekti dan Tjitrosudibyo, Kitab Undang-Undang Hukum Perdata (Jakarta: Pradnya Paramita, 2005)

Suhardi, Gunarto, Peranan Hukum Dalam Pembangunan Ekonomi (Yogyakarta: Universitas Atmajaya, 2002)

Yani, Ahmad dkk., Seri Hukum Bisnis Perseroan Terbatas (Jakarta: PT. Raja Grafindo Persada, 2000)

\section{Makalah/Artikel/Prosiding/Hasil Penelitian}

Budiyono, Herlien, "Arah Pengaturan Undangundang Nomor 40 Tahun 2007 tentang Perseroan Terbatas dalam Menghadapi Era Global", Jurnal Rechtsvinding Media Pembinaan Hukum Nasional Volume 2 Nomor 2 (2012)

Juwana, Hikmahanto, "Arah Kebijakan Pembangunan Hukum di Bidang Perekonomian dan Investasi", Majalah Hukum Nasional, No. 2 (2008)

La Porta, Rafael, Florencio Lopez-de-Silanes, Andrei Shleifer, and Robert W. Vishny, "Investor Protection and Corporate Governance", Journal of Financial Economics Vol. 58 (2000)

Khairandy, Ridwan, "Perseroan Terbatas sebagai Badan Hukum", Jurnal Hukum Bisnis, Volume 26 Nomor 3 (2007)

Koessler, Maximilian, "The Person in Imagination or Persona Ficta of the Corporation", Lousiana Law Review Vol. 9 No. 4 (1949)

R. Setiawan, "Perbandingan Peraturan-peraturan Perseroan Terbatas Menurut Hukum Indonesia (KUHD) Belanda (WvK) dan Inggris (CompaniesAct)" Padjadjaran Jilid IV No. 3-4 (1973)

Rusli, Hardijan, "Metode Penelitian Hukum Normatif: Bagaimana?", Law Review Fakultas Hukum Universitas Pelita Harapan Volume V No. 3 (2006)

Sitompul, Zulkarnain, "Investasi Asing di Indonesia Memetik Manfaat Liberalisasi", Jurnal Legislasi Indonesia, Vol. 8 (2008)
Theberge, Leonard J., "Law and Economic Development", Journal of International Law and Politics Vol. 9 (1989)

\section{Internet}

Antara, "Paket Ekonomi XII Naikkan Peringkat Kemudahan Berusaha", http://www.antaranews. com/berita/557836/ (diakses 25 Juni 2017)

Bappenas, "Paket Kebijakan XII Pemerintah Pangkas Izin, Prosedur, dan Waktu Untuk Kemudahan Berusaha di Indonesia". https://www.bappenas. go.id/.../ (diakses 4 Juni 2017)

BPKM, "BKPM, Sebagian Besar Deregulasi Perbaikan Kemudahan Telah Diselesaikan", siaran pers BKPM 22 Maret 2017. www.bkpm.go.id (diakses 20 Juni 2017)

BKPM, "Rencana Strategis (RENSTRA) BKPM Tahun Anggaran 2015-2019", http://www.bkpm.go.id/ (diakses 30 Mei 2107)

BKPM, "Laporan Kinerja Badan Koordinasi Penanaman Modal Tahun 2016", http://www. bkpm.go.id/ (diakses 3 Juli 2017)

Direktorat Jenderal Aministrasi Hukum Umum, "Direktorat Jenderal Administrasi Hukum Umum Online", http://www.ahu.go.id (diakses 22 Juni 2017)

Doing Business, "Peringkat yang dipublikasikan oleh Bank Dunia" http://www.doingbusiness.org/ rankings. (diakses 24 Mei 2017)

EODB, "Starting a Business", http://eodb.ekon. go.id/indikator-eodb/starting-a-business/ (diakses 24 Juni 2017)

Hukum Perseroan Terbatas, "Permohonan Melalui Media Elektronik", http://www. hukumperseroanterbatas.com (diakses $14 \mathrm{Mei}$ 2017)

Suara Merdeka, "Indonesia Lima Besar Kekuatan Ekonomi Dunia", berita.suaramerdeka.com (diakses 12 Maret 2017)

\section{Peraturan}

Undang-Undang Dasar Negara Republik Indonesia Tahun 1945

Ketetapan Majelis Permusyawaratan Rakyat Republik Indonesia tentang Politik Ekonomi dalam Rangka Demokrasi Ekonomi, TAP MPR RI Nomor XVI/MPR/1998

Undang-Undang Nomor 3 Tahun 1982 tentang Wajib Daftar Perusahaan 
Undang-Undang Nomor 37 Tahun 2004 tentang Kepailitandan Penundaan Kewajiban Pembayaran Utang

Undang-Undang Nomor 25 Tahun 2007 tentang Penanaman Modal

Undang-Undang Nomor 40 Tahun 2007 tentang Perseroan Terbatas

Undang-Undang Nomor 20 Tahun 2008 tentang Usaha Mikro, Kecil dan Menengah.

Undang-Undang Nomor 1 Tahun 2013 tentang Lembaga Keuangan Mikro

Peraturan Pemerintah Nomor 7 Tahun 2016 tentang Perubahan Modal Dasar Perseroan Terbatas

Peraturan Pemerintah Nomor 45 Tahun 2016 tentang Penerapan Tarif PNBP di Lingkungan Kementerian Hukum dan HAM

Peraturan Menteri Hukum Dan Hak Asasi Manusia Nomor 1 Tahun 2016 tentang Perubahan Atas Peraturan Menteri Hukum Dan Hak Asasi Manusia Nomor 4 Tahun 2014 Tentang Tata Cara Pengajuan Permohonan Pengesahan Badan Hukum Dan Persetujuan Perubahan Anggaran Dasar Serta Penyampaian Pemberitahuan Perubahan Anggaran Dasar Dan Perubahan Data Perseroan Terbatas
Peraturan Menteri Hukum Dan Hak Asasi Manusia Nomor 2 Tahun 2016 tentang Tentang Tata Cara Pengajuan Permohonan Pengesahan Badan Hukum Dan Persetujuan Perubahan Anggaran Dasar Serta Penyampaian Pemberitahuan Perubahan Anggaran Dasar Dan Perubahan Data Yayasan

Peraturan Menteri Hukum Dan Hak Asasi Manusia Nomor 3 Tahun 2016 tentang Tata Cara Pengajuan Permohonan Pengesahan Badan Hukum Dan Persetujuan Perubahan Anggaran Dasar Serta Penyampaian Pemberitahuan Perubahan Anggaran Dasar Dan Perubahan Data Perkumpulan

Peraturan Menteri Hukum Dan Hak Asasi Manusia Nomor 2 Tahun 2017 tentang Perubahan atas Permenkumham Nomor 11 Tahun 2016 Tentang Imbalan Jasa Kurator dan Pengurus sebagai bentuk pembaruan dalam mengatasi permasalahan kepailitan

Peraturan Menteri Hukum Dan Hak Asasi Manusia Nomor 3 Tahun 2017 tentang Jasa Hukum Notaris Untuk Pendirian Perseroan Terbatas Bagi Usaha Mikro, Kecil dan Menengah (UMKM) 